\title{
INVESTIGATION OF THE IMPACT of Forest Fires on the Chemistry AND QuALITY OF GROUND WATER in Yellowstone National Park
}

\author{
Donald D. RunNells + Mary Siders \\ Department of GEOLOGICAL SCIENCES $\uparrow$ UnIVERSITY of Colorado \\ BOULDER
}

\section{$\downarrow \quad$ Project Objectives}

\section{PURPOSE OF THE INVESTIGATION}

In order to investigate the impact of the 1988 forest fires on the chemistry and water quality of shallow ground water in Yellowstone National Park, a two-year regime of sampling and analysis was begun in August, 1989. Samples from ground-water wells for which pre-fire chemical data could be obtained were selected for this study.

Although it may have been anticipated that the surface waters would show some effects of the fire, in terms of increased sedimentation and the addition of ash-laden runoff, the effects of the fire on ground water are less predictable. The purpose of this investigation is to determine the character and extent of these effects.

\section{Research ObJectives}

The main objective of this study is to define the chemistry, transport, and fate of dissolved components entering the ground water as a result of the forest fires of 1988.

Specific objectives that are being addressed by this investigation include:

1. Determination of chemical and physical properties of the ground water by means of geochemical analyses performed in the laboratory and in the field.

2. Sampling and chemical analyses of soil water (i.e. water from the unsaturated zone).

3. Leaching of ash and soil samples and chemical analysis of the aqueous extracts.

4. Comparison of the analytical results for the post-burn waters with the pre-fire database. These comparisons will be made on a component by component basis. Results will be assessed with respect to the pre-fire data, as well as to the mineralogies of soil and bedrock, and the chemical composition of the ash leachates.

5. Computer modeling of the analytical data, using the geochemical modeling programs PHREEQE (Parkhurst et al. 1980) MINTEQA2 (Environmental Protection Agency 1989), and BALANCE (Parkhurst et 
al. 1982), to assess transport and fate of ashderived solubles.

\section{HYPOTHESES TO BE TESTED}

We anticipate that the impact of the forest fires on ground-water chemistry will be more subtle than the chemical and physical effects on surface waters in the Park. We envision a "front" of downward-migrating leachate, containing components dissolved from the ash. The soil and regolith in this case should act much like the ion-exchange resin of a chromatography column. That is, different components will migrate with different rates of attenuation and adsorption. Some dissolved constituents will probably never reach the water table due to their uptake by plants or adsorption onto clays and other components in the regolith.

The bulk of precipitation in Yellowstone National Park occurs as snowfall during the winter months, with infrequent scattered thunderstorms during the summer months (Dirks and Martner 1982). Ground-water recharge in the greater Yellowstone area therefore occurs mainly in the spring and early summer months as a result of percolation of snowmelt through the unsaturated zone. To monitor the progress of this recharge, twenty vacuum lysimeters were installed in April, 1990. By sampling the soil water collected at four different depths, we may be able to track the downward migration of ash-derived components and thereby test our hypothesis.

In addition to tracking the chemical constituents known to be leached from the ash, we are also investigating the use of isotopic tracers. Specifically, we plan to examine the wood ash and ground water for radioactive Sr-90 (Farber 1990) to determine if relevant information can be gained from such analysis.

\section{Research Status}

\section{INTRODUCTION}

During the period from August, 1989 to November, 1990, one reconnaissance trip and seven sampling trips were made. In addition to the groundwater samples, soil-water samples were also collected and analyzed during 1990. Ash-extraction studies, which began in March, 1990, will continue throughout the first half of 1991. The results of these three facets of our study are presented and discussed below.

\section{Ground Water Sampling Sites}

The four sites of sampling for ground water are centrally located in Yellowstone National Park. These sites include: Fishing Bridge (no burn), Madison Junction (light to no burn), Old Faithful (moderate burn), and Grant Village (heavy burn).

\section{RESULTS}

Concentrations of ferrous iron were insignificant for all wells except MJ-9.

All samples collected in 1989 were analyzed for arsenic by graphite furnace atomic absorption spectroscopy (GFAA). Because all samples contained concentrations of arsenic far below the Drinking Water Standard (DWS) of $50 \mathrm{ug} / \mathrm{L}$ recommended by the U.S. EPA (1976), it was decided not to continue analyzing arsenic in all samples, unless time allowed. Thermal waters in the Park commonly contain high levels of arsenic (Stauffer et al. 1980), so data suggest that thermal input is minor in the ground waters examined for this study.

Although large amounts of particulate charcoal and ash have been observed in the surface waters in Yellowstone (July, 1989, personal observations), the low concentrations of dissolved organic carbon (DOC) seen in all of the wells sampled to date indicate that carbon-rich waters have not yet, or will not, reach the water table. The average concentration for DOC in rivers is $5.75 \mathrm{mg} / \mathrm{L}$ (Hem 1985). The concentrations in ground water are normally less, due to adsorption of organics as the waters pass through the unsaturated zone. As summarized by Thurman (1985), the "DOC in ground water ranges from 0.2 to $15 \mathrm{mg} / \mathrm{L}$ with a median concentration of $0.7 \mathrm{mg} / \mathrm{L}$. the majority of all ground waters have concentrations below $2 \mathrm{mg} / \mathrm{L}$." Because of the low concentrations of DOC measured in the ground-water samples, it was decided to sample for DOC only on an annual basis. 


\section{VARIATIONS IN GROUND-WATER CHEMISTRY WITH TIME}

Most wells exhibited no well-defined trends in ground-water composition over the course of fourteen months, from August, 1989 to late October, 1990. Samples from well GV-1 seem to show a cyclical trend in composition, although this could be attributed to dilution following snowmelt and subsequent concentration of solutes as the season progresses. As noted earlier, the bulk of recharge to the ground water comes as a result of snowmelt. In the case of well GV1 , this would assume a period of recharge nearly instantaneous with the period of snowmelt (i.e. very rapid percolation of melt waters through the unsaturated zone and into the ground water of the saturated zone), or a coincidental one-year lag in the response of ground water to snowmelt. The former explanation seems more probable, especially in view of the very shallow water table (about $2 \mathrm{~m}$ ) in the vicinity or well GV-1.

\section{COMPARISON TO HISTORICAL DATA}

Although up-gradient wells were specifically selected for this study, the first factor that must be taken into account when examining the water chemistry is possible chemical impact from adjacent wastewater treatment facilities. The impact of the sewage effluent is best seen as an increase in the values for $\mathrm{Cl}, \mathrm{No}_{3}$ and conductivity between our data and those of Cox (1979) for specific wells at the Fishing Bridge (FB-1 and FB-2) and Madison Junction (MJ-4) sites. By studying these three parameters, the extent of chemical modification resulting from sewage effluent entering the local ground water can be determined. It is clear that the ground waters intercepted by wells MJ-4, FB-1, and FB-2 have all been markedly affected by the sewage effluent since the analyses of Cox (1979). In wells FB-1 and FB-2 especially, the effluent has altered the chemistry of the ground water. As levels of the anions from the effluent $\left(\mathrm{Cl}\right.$ and $\mathrm{NO}_{3}$ ) increased, there was a parallel increase in cation concentrations. The concentrations of major cations ( $\mathrm{Ca}, \mathrm{Mg}, \mathrm{K}$, and $\mathrm{Na}$ ) in wells FB-1 and FB-2 doubled, or more than doubled from the period of 1977 to 1989 . The chemistry of the ground water from the other wells sampled for this study appears to be little affected by the sewage effluent.
In light of the knowledge that the water chemistry in wells FB-1 and FB-2 has changed so drastically, the use of these wells as "background controls" is diminished. Fortunately, for the purposes of this study, wells MJ-1 and MJ-7 can be used as background. The chemistry of the water from these two wells has changed little due to the effects of the nearby treatment plant. The immediate area around these wells is unburned, although surrounding cliffs have sustained some degree of burning.

The chemistry of ground water at the most severely burned site (Grant Village) has not changed appreciably since the mid-1970s, nor during the first year of this study. At this time, waters from wells GV$1, \mathrm{GV}-5, \mathrm{GV}-6, \mathrm{GV}-10 \mathrm{~A}$, and GV-10 show no significant changes in chemical compositions that may be directly attributable to the 1988 forest fires.

\section{ASH-EXTRACTION STUDIES}

To date, only one half of the ash samples collected have been leached and their aqueous extracts. Trends seen in the results of the three extractions include:

1. a trend for the concentrations of some ions to drop off sharply with successive extractions (eg. $\mathrm{SO}_{4}, \mathrm{Ca}, \mathrm{K}, \mathrm{Mg}$ ),

2. a fairly constant concentration for other ions $\left(\mathrm{eg} . \mathrm{SiO}_{2}\right)$, and

3. a trend of increasing levels of some other ions (eg. PO) in some samples.

Shown graphically for results from resh ash, collected immediately after the fires and prior to any precipitation (Figures 9a to 10b), these trends are visible. The trends correspond to (respectively):

1. dissolution of soluble salts,

2. equilibrium with a solid phase present, and

3. possible oxidation or microbial decay of organic components.

The fresh ash, which was collected in 1988 prior to any leaching by precipitation, contains high concentrations of water-soluble $\mathrm{Ca}, \mathrm{K}, \mathrm{Mg}, \mathrm{SiO}_{2}$, and $\mathrm{SO}_{4}$. Alkalinity and $\mathrm{pH}$ of these fresh samples are also elevated with respect to values for the shallow, nonthermal ground waters of the Park. Comparison of the analytical results from the first round of extractions of ash samples collected from the same localities one year after the fires, with samples collected in 1988 immediately after the fires, show decreased concentrations of all the above constituents (i.e. 
samples collected one year after the fires show the effects of leaching by precipitation).

It is also interesting to note that the samples collected one year after the fires were subject to further leaching for some components. Our data suggest that ash-derived components may continue to be leached for at least several years after the fires.

\section{$\downarrow$ SUMmary}

Results from the ash-extraction studies will be valuable for assessing the changes in ground-water chemistry, which may occur as a direct result of the 1988 forest fires, by providing a measure of the solutes released during weathering of the ash.

The extractions performed on wood ash, collected from throughout the Park, have identified the chemical components of the ash, as well as their relative abundances. From this work, it is clear that the ash contains large amounts of soluble material. However, the levels of alkalinity and the $\mathrm{pH}$ of the ash leachate were lower than expected. Consequently, no appreciable increase in the alkalinity and $\mathrm{pH}$ of the ground waters is anticipated as a result of the forest fires.

Substantial amounts of some essential elements required by plants $(\mathrm{Ca}, \mathrm{Mg}, \mathrm{K})$ are quickly released from the ash upon wetting. Nutrients $\left(\mathrm{NO}_{3}, \mathrm{PO}_{4}\right)$ appear to be released more slowly, possibly as the result of oxidation of or microbial action on the ash.

\section{LYSIMETER SAMPLES}

Vacuum lysimeters, which were installed in April, 1990, have been sampled four times. Time needed for equilibrium to be restored in the soil profile, following the installation of the lysimeters, has been estimated to be as long as a full year (Litaor 1988). Although care was taken to reconstruct the soil profile, early results from the lysimeter sampling program should be viewed with caution.

High observed levels of chloride and low values of $\mathrm{pH}$ are most likely the result of incomplete flushing of the $\mathrm{HCl}$ used in cleaning the lysimeters. Because of this, these early results (May and June, 1990) will have little validity as measures of the true composition of the soil solution. As expected, however, the data from the September and october, 1990, show significant improvement over the earlier results.

Results for the first year of lysimeter sampling show the movement of the wetting front (from snowmelt) downward through the unsaturated zone. At sites that experienced an early snowmelt (e.g. Madison Junction), no water was present and no samples were collected from the shallower (15 and 30 $\mathrm{cm}$ ) lysimeters. At the Old Faithful and Grant Village sites, more samples were collected from the 60 and 90 $\mathrm{cm}$ depths in June than in May. These results are encouraging and suggest that it should be possible to track the downward migration of constituents leached from the ash.

According to Fahey and Knight (1986), the $\mathrm{pH}$ of the soil solution in a lodgepole pine forest should have values of about 5.5 to 6.0. This range of $\mathrm{pH}$ is approached or attained by most samples. We expect complete equilibration of the lysimeters to be achieved by the spring of 1991, and this should be seen in the next set of samples.

\section{Literature Cited}

Cox, E. R. 1979. Preliminary study of wastewater movement in Yellowstone National Park, Wyoming, October 1976 through September 1977; U.S. Geological Survey Open-file Report 79-684, $59 \mathrm{p}$.

Dirks, R. A. and B. E. Martner. 1982. The climate of Yellowstone and Grand Teton National Parks: National Park Service Occasional Paper Number Six, 26 p.

Fahey, T. J. and D. H. Knight. 1986. Lodgepole pine ecosystems: BioScience 36:610-617.

Farber, S. 1990. Preliminary study of Cs-137 uptake by trees and its implication for BRC, waste disposal, and dosimetry: Health Physics Soc. Newsl. 18(4):2-5.

Hem, J. D. 1985. Study and Interpretation of the Chemical Characteristics of Natural Water: U.S. Geological Survey Water-Supply Paper 2254, Third Edition, 263 p.

Litaor, M. I. 1988. Review of soil solutions samplers: Water Res. Res. 24:727-733. 
Parkhurst, D. L., D. C. Thorstenson, and L. N.

Plummer. 1980. PHREEQE computer program:

U.S. geological Survey Water-Resources

Investigations, 80-96, $210 \mathrm{p}$.

Parkhurst, D. L., L. N. Plummer and D. C.

Thorstenson. 1982. BALANCE computer

program: U.S. Geological Survey Water-

Resources Investigations 82-14, $216 \mathrm{p}$.

Thurman, E. M. 1985. Organic Geochemistry of Natural Waters, Martinus Nijhoff/Dr W. Junk Publishers, Amsterdam. 497 p. 